\title{
TESTING SUSTAINABLE CONSUMPTION BEHAVIOR IN ITALY AND PAKISTAN
}

\author{
Muhammad Ishtiaq Ishaq ${ }^{1}$ \\ ${ }^{1}$ Imperial College of Business Studies, Lahore, Pakistan
}

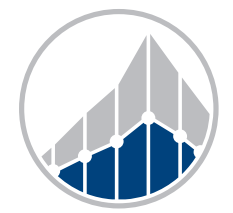

EUROPEAN JOURNAL OF BUSINESS SCIENCE AND TECHNOLOGY

Volume 4 Issue 1 ISSN 2336-6494 www.ejobsat.com

\begin{abstract}
The purpose of this empirical research is to determine the relative impact of food safety concern, ethical concern and health consciousness on the theory of planned behavior dimensions. Moreover, this study also ascertains the impact of the theory of planned behavior dimensions (attitude, subjective norms, and perceived behavioral control on repurchase intentions of organic food among Pakistan and Italian consumers. A highly structured questionnaire is used to collect the data from 337 consumers from Italy and 314 consumers living in Pakistan. As proposed by the researchers, measurements invariance tests are used to analyze the cultural differences (if any) and subsequently structural equation modeling is used to determine the study hypotheses. The study results revealed mix findings and demonstrated significant differences between Pakistani and Italian consumers.
\end{abstract}

\section{KEY WORDS}

ethical concern, food safety concern, theory of planned behavior, cross-cultural differences

\section{JEL CODES}

M31, Q01, Q56

\section{INTRODUCTION}

In recent years, the consumers are facing various food hazards in food consumptions including bovine spongiform encephalopathy; herbicide resides pesticides, genetic modification, and food poisoning (McCluskey et al., 2005; Christoph et al., 2008). Due to these reasons, the organic food market has seen swift market growth to reduce the herbicides, pesticides, and fertilizers (Lee et al., 2014; Kim et al., 2013). As per Organic Trade Association statistics, the organic food market grows $\$ 27$ billion in the United States in spite of a struggling economy. Even though the organic food offerings are increasing and retailers' desire to market more 
organic food, there are numbers issues in buying this kind of food due to limited availability, higher quality skepticism, and premium prices (Lea and Worsley, 2005).

Sustainability and social responsibility are important topics in recent marketing research literature (Yoo et al., 2011; Lee et al., 2014; Ishaq and Di Maria, 2018). In general, the ethical consumer shows his ethical responsibility through his/her buying intentions whereas he/she is also willing to pay premium prices for ethical-backed good and services (DiPietro et al., 2013; Ishaq and Di Maria, 2018). The existing academic literature related to consumer attitudes, motives and purchase intentions towards organic food behavior is very scarce (Newsom et al., 2005) and had mix results. For instance, the studies of Lea and Worsley (2005) and Lockie et al. (2004) primarily focuses on identifying motives to buying behavior of organic food and found that nutritional information and health are major motives for purchasing. However, the studies of Çabuk et al. (2014) and Manaktola and Jauhari (2007) found that the consumer behavior does not link with positive attitudes of consumers. Several studies have shown that price sensitivity is also an important factor to buy organic food as compared to conventional food. These impediments are considered as reasons for attitude-behaviorgap in organic food buying because the positive attitudes do not always support the purchasing decisions.

Till date, multiple empirical studies have been conducted to analyze the consumers' purchase behavior towards organic food. The one group mainly focuses on the influence of consumer motives on the organic food and found that the nutritional and health motives are a most influential factor that pushed the consumer to buy the organic food (Lea and
Worsley, 2005; Lockie et al., 2004). Williams and Hammitt (2000) claimed that some consumers prefer the organic food to establish healthier eating habits and positive gains. Another strong motive appeared in the literature is an environmental concern (Magnusson et al., 2003), but with mixed results (Çabuk et al., 2014).

Some of the key and primary motivating factors identified for current study are food safety, environment, and health (Hughner et al., 2007; Smith and Paladino, 2010; Hoefkens et al., 2009; Nardalı and Ay, 2008; Lodorfos and Dennis, 2008; Hamzaoui-Essoussi and Zahaf, 2008; Hwang, 2016; Lee et al., 2015; Çabuk et al., 2014). Despite these empirical findings, some studies also found that the food safety, health, and environment is not a strong predictor of repurchase intentions and consumer attitudes to buying organic food (Smith and Paladino, 2010; Michaelidou and Hassan, 2008; Tarkiainen and Sundqvist, 2005). Hence, it cannot be argued that these key motivating factors have the same importance in consumers' mind about buying organic food.

The food choice motives have been explored numerous times (Lee et al., 2015; Çabuk et al., 2014; Chen et al., 2007), but, no study has been conducted to identify the relative impact of organic food buying behavior among consumers of a developed economy and emerging economy in the world. Accordingly, the purpose of this research is to determine the relative impact of environmental concern, health consciousness and food safety concern on Theory of Planned Behavior (TPB) dimensions (attitude, subjective norms, and perceived behavioral control). Additionally, this research also explores the impact of TPB dimensions on purchase intentions of Italian and Pakistani consumers who are buying organic food. 


\section{HYPOTHESES DEVELOPMENT}

\subsection{Health Consciousness and TPB}

The scandals in food, allergy in children, and the negative influence of biotechnological advancement in agricultural products on environment and health (Çabuk et al., 2014; Rimal et al., 2006; Lee et al., 2015) had increased the consumer's interest to be health conscious and buying organic food. Michaelidou and Hassan (2008) argued that consumers having health concerns are interested in healthier behavior, good quality life and buying a pattern to prevent illnesses. This health consciousness is such a vital encouraging factor for the consumers that many studies have been conducted to determine the actual purchase behavior and intention to buy (Nardall and Ay, 2008).

Magnusson et al. (2003) claimed that health is considered as a relatively strongest influencer for repurchase intentions, frequent buying behavior, and attitude towards purchasing organic foods. Many studies have shown the consumer preferences towards organic food because of healthier which shaped the purchase attitudes (Hoefkens et al., 2009; Hamzaoui-Essoussi and Zahaf, 2008). The study of Michaelidou and Hassan (2008) also claimed that health consciousness has a significant impact on purchase attitudes regarding organic food. As far as the cultural differences are concerned, Squires et al. (2001) shown differences of opinion among Dutch and New Zealander consumers. The Dutch consumers prefer environment while New Zealand consumers prefer health as the strongest predictor of organic food consumption. Based on these results, it can assume that the health consciousness influences consumers attitudes, subjective norms and perceived behavior control (PBC) in buying organic food.

$H_{1}$ : Health consciousness has a positive impact on TPB dimensions (attitudes, subjective norms, and $P B C)$.

\subsection{Environmental Concern and TPB}

The environmental concern is also taken as an important factor in buying organic food. As compared to conventional food, the organic food is considered as more environmental friendly products which put less harm to the earth and also beneficial for the environment (Grønhøj and Ölander, 2007; HamzaouiEssoussi and Zahaf, 2008; Hwang, 2016). The literature states that consumers are actively consuming that food which they perceived little harmful to the environment, and are sustainable, and ecological friendly (Zanoli and Naspetti, 2002).

In contrast to these results, some studies also found adverse results on the relationship of organic food consumption and the environment. Verhoef (2005) claimed that organic food consumption does not have any significant impact on buying intentions and preference for organic food. The studies of Çabuk et al. (2014), Yadav (2016), and Lee et al. (2015) found a positive impact on buying attitudes of organic food. Based on these results, it can assume that:

$\mathrm{H}_{2}$ : Environmental concern has a positive impact on TPB dimensions (attitudes, subjective norms, and $P B C)$.

\subsection{Food Safety and TPB}

The rapid growth in pain relievers, hormone, animal residues, toxins, food additives, bacteria and pesticide residuals in food have increased distrust on the quality and edibility of food concerns (Rimal et al., 2005). Moreover, it is also not claimed that the quality and integrity of organic food is also safer than conventional food. However, there is limited scientific evidence are available which claimed that the consumption of organic food is healthier and safer (Magkos et al., 2006). 
Numerous studies also take food safety concern as an important motivating factor to buy organic food (e.g., Çabuk et al., 2014). Rimal et al. (2005) claimed that the perception regarding food safety risk is significantly different between the consumers who prefer organic food versus the consumers who buy conventional food. The organic food buyers perceived that the potential risk of pesticides in organic food is relatively low when it compared to conventional food. For this reason, the consumers are ready to pay premium prices (Williams and Hammitt, 2000).

Similar to environmental concern and health consciousness research studies, food safety concern also has mixed results. Michaelidou and Hassan (2008) found that food safety concern has a positive influence on attitudes towards organic food but insignificant impact on intention to buy. Since the majority of studies claimed the impact of food safety concern on purchasing attitudes; it can assume that food safety concern influence TPB's dimension among Pakistan and Italian consumers. Therefore,

$\mathrm{H}_{3}$ : Food safety concern has a positive impact on TPB dimensions (attitudes, subjective norms, and $P B C)$.

\subsection{TPB Dimensions and Purchase Intentions}

Numerous theories are available to understand the human behavior, the theory of planned behaviour (TPB) is considered as the key theory to understand the wide ranges of behaviours (Ajzen, 1991). This theory is implemented in various contexts including the adoption of IT, alcohol consumption, hoteling industry and travel destination choices (Hsu and Huang, 2012).

The recent studies revealed that the attitudes towards organic food strongly predict the buying intentions (e.g., Gracia Royo and de Magistris, 2007). A significant and relatively strong relationship has been in previous studies in diverse settings (Michaelidou and Hassan, 2008; Lee et al., 2015). Tarkiainen and Sundqvist (2005) claimed that the consumer attitudes influenced organic food's buying intentions. Moreover, the same result also found in the study of Chen et al. (2007) study.

The subjective norms explain the social pressure perceives by an individual when he/she engages him/herself in a behavior. The study of Sparks et al. (1995) contended that the subjective norm is one of the weakest predictors of buying intentions whereas the study of Chen et al. (2007) and Armitage and Conner (2001) demonstrated subjective norm as a strong influence on repurchase intentions regarding organic food.

The third aspect of TPB is perceived behavior control which refers to self-control in a given situation while taking the benefits and risks associated with that specific behavior. The studies of Chen et al. (2007) and Godin and Kok (1996) reported the positive influence of PBC on buying intentions. Based on these results, the following hypothesis states as:

$\mathrm{H}_{4}$ : TPB dimensions (attitudes, subjective norms, and $P B C$ ) have a significant impact on purchase intentions.

\section{RESEARCH METHODOLOGY}

The conceptual model tested in this study is presented in Fig. 1. The academic literature contains two stand-out approached to understand and analyze the cross-cultural examinations; the etic approach and the emic approach. This study uses an etic approach where a researcher collects the data from two culturallydifferent populations and explore the differences (if any). Using self-administered and survey research approach, the data is collected from consumers of different ages living in Italy and Pakistan. To determine the sample representativeness, Kline (2011) proposed that data should be collected from 10 respondents against each measuring item. In this study, the total measuring items are 31 , so the sample should be 310 from each country. Accordingly, the questionnaire is distributed using a convenience 


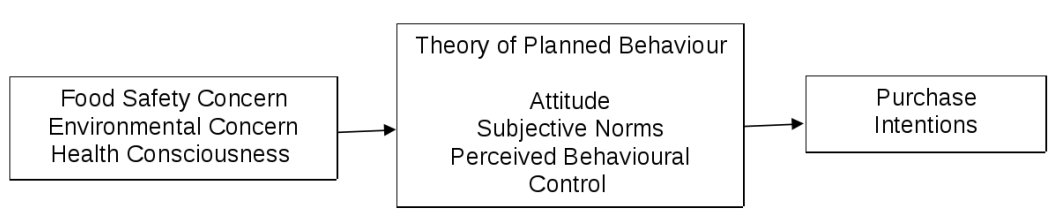

Fig. 1: Conceptual Framework of this Study

sampling method to the 400 Italian and 400 Pakistani consumers living in urban cities. In the end, 337 questionnaires are in usable condition from an Italian sample while 314 responses are filled by Pakistani respondents. The response rate is $84 \%$ and $79 \%$ of Italian and Pakistani sample respectively. The said number of respondents indicated the sample representativeness from each sample. The data is collected during January and February 2018 from Pakistan whereas the data collection in Italy is done during October and November 2017.

Among Italian respondents, $53 \%$ respondents are female whereas the male accounted for $47 \%$. Concerning age, $23 \%$ respondents have age less than 25 years old, while $46 \%$ have age between 26 and 35 years and $31 \%$ respondents have an age greater than 35 years. A total of $66 \%$ of respondents are single while $30 \%$ are married and $4 \%$ do not disclose their marital status. With respect to Pakistani sample, 69\% respondents are male while only $31 \%$ are female. Majority of the respondents $(52 \%)$ having age between 26 and 35 years of age. For marital status, $59 \%$ of respondents are married while $41 \%$ are single.

Although, the previous studies related to organic food consumption conducted in crosscultural settings (e.g., Squires et al., 2001; McEachern and McClean, 2002; Tsakiridou et al., 2008; Schifferstein and Oude Ophuis, 1998), but in the almost same cultural environment as per Hofstede cultural theory. This current study is first of its kind that collected the date from two countries that that economically and culturally different. Both cultures are distinguished and exemplified at a different level in the cultural study of Hofstede (1991). Engelen and Brettel (2011) claimed that the individualism-collectivism dimension is most important to determine the cultural differences. Moreover, around $52 \%$ of studies conducted in a cross-cultural context are mainly focused on the said dimension. According to this dimension, Pakistan is considered as one of the most collectivistic country having a score of 14 whereas the Italian environment is purely individualistic with 76 score.

The highly structured questionnaire is designed to collect the responses purchase intentions, perceived behavioral control, subjective norms, purchase attitudes, health consciousness, and environmental concerns. The theory of planned behavior's dimensions is adapted from the scale of Bredahl (2001) where 4-items are used to measure purchase attitude, 3 -items are used for the subjective norm, and 4 -items are used to determine perceived behavioural control. The 4-items related to purchase intentions towards organic food are taken from the studies of Pliner and Hobden (1992) and Bredahl (2001) whereas 7-items are taken from Williams and Hammitt (2000), McEachern and McClean (2002) and Michaelidou and Hassan (2008) to measure food safety concerns. The environmental concern (4-items) and health consciousness (6-items) are taken from the studies of Roberts and Bacon (1997) and Michaelidou and Hassan (2008) respectively. The responses are collected on a 5-point Likert scale where $1=$ strongly disagree, and $5=$ strongly agree. 


\section{STUDY RESULTS}

Tab. 1 shows the descriptive statistics of all independent and dependent variables. The statistics included mean, standard deviation, composite reliability, and average variance extracted. The results showed that the internal consistency is significantly established as the values are above 0.70 for both samples.

Tab. 1: Descriptive Statistics

\begin{tabular}{|c|c|c|c|c|}
\hline Variable & Mean & Std. Dev. & CR & AVE \\
\hline $\begin{array}{l}\text { Health } \\
\text { Consciousness (HC) }\end{array}$ & 4.18 & 0.55 & 0.93 & 0.64 \\
\hline $\begin{array}{l}\text { Environmental } \\
\text { Concern (EC) }\end{array}$ & 4.08 & 0.35 & 0.92 & 0.66 \\
\hline $\begin{array}{l}\text { Food Safety } \\
\text { Concern (FSC) }\end{array}$ & 4.10 & 0.70 & 0.94 & 0.70 \\
\hline $\begin{array}{l}\text { Purchase } \\
\text { Attitude (PA) }\end{array}$ & 4.49 & 0.62 & 0.91 & 0.73 \\
\hline $\begin{array}{l}\text { Subjective } \\
\text { Norm (SN) }\end{array}$ & 4.60 & 0.54 & 0.90 & 0.67 \\
\hline $\begin{array}{l}\text { Perceived Behavior } \\
\text { Control (PBC) }\end{array}$ & 4.24 & 0.58 & 0.89 & 0.65 \\
\hline $\begin{array}{l}\text { Purchase } \\
\text { Intentions (PI) }\end{array}$ & 4.20 & 0.71 & 0.83 & 0.65 \\
\hline
\end{tabular}

Tab. 2 provides the correlation results of Pakistani sample. All the correlations are positive and significant. The results indicated that the highest correlation of health consciousness is with the subjective norm $(r=0.335)$ whereas the lowest correlation is with food safety concern $(r=0.187)$. The highest correlation of environmental concern is with purchase attitude $(r=0.349)$ whereas the lowest correlation is with subjective norm $(r=0.287)$. The highest correlation of purchase intentions is with health consciousness $(r=0.335)$ whereas the lowest correlation is with perceived behavioral control $(r=0.183)$.

Tab. 3 provides the correlation results of the Italian sample. All the correlations are positive and significant. The results indicated that the highest correlation of health consciousness is with the subjective norm $(r=0.360)$ whereas the lowest correlation is with food safety concern $(r=0.187)$. The highest correlation of environmental concern is with food safety concern $(r=0.332)$ whereas the lowest correlation is with the subjective norm $(r=0.277)$ and so on. The highest correlation of purchase intentions is with health consciousness $(r=$ 0.311 ) whereas the lowest correlation is with perceived behavioral control $(r=0.178)$.

Since the scales of independent and dependent variables are taken from previous studies; hence confirmatory factor analysis is run using AMOS 18 to determine the validity of scales and model fitness separately for both cultures (Kline, 2010). The model fitness of Pakistani sample is $\chi^{2}=305.84$ with 98 df $(p<0.001$, $\left.\chi^{2} / \mathrm{df}=3.12\right)$ while GFI $=0.93, \mathrm{NFI}=0.98$, $\mathrm{IFI}=0.92, \mathrm{CFI}=0.91$ and $\mathrm{RMSEA}=0.061$ whereas the Italian sample's model fitness is $\chi^{2}=329.51$ with $108 \mathrm{df}\left(p<0.001, \chi^{2} / \mathrm{df}=\right.$ $3.05)$ while $\mathrm{GFI}=0.95, \mathrm{NFI}=0.97, \mathrm{IFI}=$ $0.91, \mathrm{CFI}=0.98$ and RMSEA $=0.074$. These statistics are indicating satisfactory results for discriminant and convergent validities for each sample.

In order to draw legitimate conclusions, measurement invariance tests are compulsory to the generalization of theories in cross-cultural contexts. Without checking these tests, the results might not be valid and flawed. The unbiased and complex method to check cultural - cultural differences is to run multi-group confirmatory factor analyses (Vandenberg and Lance, 2000). The measurement invariance is stated if the difference of model fit indices (CFI and $\triangle \mathrm{CFI}$ ) from two multi-group confirmatory factor analysis is between -0.01 to 0.01 (Cheung and Rensvold, 2002).

There are two methods to check measurement invariances among two different cultures. The first method is to check configural invariance through multi-group CFA. If the model shows adequate model fitness, then it represents that the data is coherent with the theory and conceptual framework across two cultures. Although $\chi^{2}$ is significant $\left(\chi^{2}(257)=843.94\right)$ whereas the other fit indices (GFI $=0.90$, RMSEA $=$ $0.052, \mathrm{NFI}=0.94), \mathrm{IFI}=0.92, \mathrm{CFI}=0.93)$ are in accordance to given threshold. These results showed the strong model equivalence in both 
Tab. 2: Correlation Results for Pakistan Sample

\begin{tabular}{|c|c|c|c|c|c|c|c|}
\hline Constructs & $\mathrm{HC}$ & EC & FSC & PA & SN & PBC & PI \\
\hline $\mathrm{HC}$ & 1.000 & $0.336^{*}$ & $0.187^{*}$ & $0.258^{*}$ & $0.299^{*}$ & $0.276^{*}$ & $0.335^{*}$ \\
\hline $\mathrm{EC}$ & & 1.000 & $0.326^{*}$ & $0.349^{*}$ & $0.287^{*}$ & $0.305^{*}$ & $0.301^{*}$ \\
\hline FSC & & & 1.000 & $0.308^{*}$ & $0.391^{*}$ & $0.346^{*}$ & $0.297^{*}$ \\
\hline PA & & & & 1.000 & $0.247^{*}$ & $0.170^{*}$ & $0.291^{*}$ \\
\hline $\mathrm{SN}$ & & & & & 1.000 & $0.212^{*}$ & $0.248^{*}$ \\
\hline PBC & & & & & & 1.000 & $0.183^{*}$ \\
\hline PI & & & & & & & 1.000 \\
\hline
\end{tabular}

Note: * denoted to 0.001 significant level.

Tab. 3: Correlation Results for Italian Sample

\begin{tabular}{|c|c|c|c|c|c|c|c|}
\hline Constructs & $\mathrm{HC}$ & EC & FSC & PA & SN & PBC & PI \\
\hline $\mathrm{HC}$ & 1.000 & $0.321^{*}$ & $0.225^{*}$ & $0.286^{*}$ & $0.360 *$ & $0.306^{*}$ & $0.311^{*}$ \\
\hline $\mathrm{EC}$ & & 1.000 & $0.332^{*}$ & $0.325^{*}$ & $0.277^{*}$ & $0.311^{*}$ & $0.299 *$ \\
\hline FSC & & & 1.000 & $0.276^{*}$ & $0.354^{*}$ & $0.302^{*}$ & $0.235^{*}$ \\
\hline PA & & & & 1.000 & $0.308^{*}$ & $0.264^{*}$ & $0.227^{*}$ \\
\hline $\mathrm{SN}$ & & & & & 1.000 & $0.272^{*}$ & $0.223^{*}$ \\
\hline PBC & & & & & & 1.000 & $0.178^{*}$ \\
\hline PI & & & & & & & 1.000 \\
\hline
\end{tabular}

Note: ${ }^{*}$ denoted to 0.001 significant level.

cultures, and hence the configural invariance is proven. The next method is to run metric invariance test where a constraint is imposed on the base model and test the model fitness. Although $\chi^{2}$ is significant $\left(\chi^{2}(378)=781.33\right)$ whereas the other fit indices (GFI $=0.92$, RMSEA $=0.037$, NFI $=0.92)$, IFI $=0.94$, $\mathrm{CFI}=0.92$ ) are within the threshold proposed by the researchers. The CFI difference between configural model and metric invariance is -0.01 which indicated that the results are statistically equivalent and comparable in both cultures.

Structural equation modeling (SEM) is used to study the path coefficients of each hypothesis in Tab. 4.
Tab. 4: Model Fit Indices for Italian and Pakistani Sample

\begin{tabular}{lcc}
\hline Construct & $\begin{array}{c}\text { Italian Sample } \\
\text { Factor Loading Range }\end{array}$ & $\begin{array}{c}\text { Pakistani Sample } \\
\text { Factor Loading Range }\end{array}$ \\
\hline HC & $0.83-0.74$ & $0.82-0.77$ \\
EC & $0.82-0.76$ & $0.80-0.78$ \\
FSC & $0.86-0.80$ & $0.87-0.83$ \\
PA & $0.84-0.82$ & $0.85-0.79$ \\
SN & $0.83-0.79$ & $0.81-0.78$ \\
PBC & $0.86-0.81$ & $0.80-0.77$ \\
PI & $0.79-0.78$ & $0.81-0.72$ \\
\hline Model Fit & Index & \\
$\chi^{2}$ & 329.51 & 305.84 \\
df & 108 & 98 \\
$\chi^{2} /$ df & 3.05 & 3.12 \\
GFI & 0.95 & 0.93 \\
NFI & 0.97 & 0.98 \\
IFI & 0.91 & 0.92 \\
CFI & 0.98 & 0.91 \\
RMSEA & 0.074 & 0.061 \\
\hline & &
\end{tabular}


Tab. 5: Measurement Invariance Results for Cross-Cultural Examination

\begin{tabular}{lcccccccc}
\hline Model & $\chi^{2}$ & df & $\chi^{2} /$ df & CFI & RMSEA & Model Comparison & $\Delta \chi^{2}$ & $\Delta$ CFI \\
\hline M1: Configural & 722.73 & 376 & 1.92 & 0.94 & 0.041 & - & - & - \\
M2: Metric & 824.20 & 399 & 2.065 & 0.93 & 0.047 & M2 - M1 & $101.47^{*}$ & -0.01 \\
\hline
\end{tabular}

Tab. 6: Regression Results through SEM

\begin{tabular}{|c|c|c|c|}
\hline Independent Variable & Dependent Variable & $\begin{array}{l}\text { Standardized Beta Weights } \\
\text { Italy }\end{array}$ & $\begin{array}{c}\text { Standardized Beta Weights } \\
\text { Pakistan } \\
\end{array}$ \\
\hline \multirow[t]{3}{*}{ Health Consciousness } & Attitude & $0.39^{*}$ & $0.30^{*}$ \\
\hline & Subjective Norm & $0.41^{*}$ & $0.42^{*}$ \\
\hline & $\mathrm{PBC}$ & $0.38^{*}$ & $0.38^{*}$ \\
\hline \multirow[t]{3}{*}{ Environmental Concern } & Attitude & $0.45^{*}$ & $0.42^{*}$ \\
\hline & Subjective Norm & $0.36^{*}$ & $0.40^{*}$ \\
\hline & $\mathrm{PBC}$ & $0.34^{*}$ & $0.34^{*}$ \\
\hline \multirow[t]{3}{*}{ Food Safety Concern } & Attitude & $0.46^{*}$ & $0.32^{*}$ \\
\hline & Subjective Norm & $0.29 *$ & $0.39 *$ \\
\hline & $\mathrm{PBC}$ & $0.43^{*}$ & $0.43^{*}$ \\
\hline Attitude & Purchase Intentions & $0.43^{*}$ & $0.38^{*}$ \\
\hline Subjective Norm & Purchase Intentions & $0.38^{*}$ & $0.34^{*}$ \\
\hline $\mathrm{PBC}$ & Purchase Intentions & $0.40^{*}$ & $0.43^{*}$ \\
\hline
\end{tabular}

Note: ${ }^{*}$ denoted to 0.001 significant level

The results revealed that the health consciousness $(\beta=0.39)$, environmental concern $(\beta=0.45)$, and food safety concern $(\beta=$ $0.46)$ has positive and relatively stronger impact on purchase attitude among Italian sample as compared to Pakistani sample [for health consciousness $(\beta=0.30)$, environmental concern $(\beta$ $=0.42)$, and food safety concern $(\beta=0.32)]$. When we take subjective norm as dependent variable, the results showed that health consciousness $(\beta=0.42)$, environmental concern $(\beta=0.40)$, and food safety concern $(\beta=0.39)$ has positive and relatively stronger impact on subjective norms of Pakistani respondents as compared to Italian consumers [for health consciousness $(\beta=0.41)$, environmental concern $(\beta=0.36)$, and food safety concern $(\beta=0.29)]$. The TPB dimensions also have positive impact on purchase intentions for both samples. Hence, the results revealed that all hypotheses are accepted and also find significantly difference between two cultures.

\section{CONCLUSION AND RECOMMENDATIONS}

In this study, the impact of health consciousness, environmental concern, and food safety concern have been determined among Italian and Pakistani consumers. Moreover, this research also explores the influence of TPB dimensions on purchase intentions. Consistent with previous findings, the results revealed the significant relationship of food safety concern, environmental concern, and health consciousness on the purchasing attitudes towards or- ganic food in both samples (Lee et al., 2015; Çabuk et al., 2014; Smith and Paladino, 2010; Magnusson et al., 2003; Honkanen et al., 2006; Michaelidou and Hassan, 2008). Also, the study findings also demonstrated the TPB dimensions has a positive influence on purchase intentions for both samples, similar to previous results (Michaelidou and Hassan, 2008; Lodorfos and Dennis, 2008; Lee et al., 2015; Gracia Royo and de Magistris, 2007). Based on these results, it 
is evident that the theory of planned behavior strongly influenced the buying intentions.

The changing in eating preferences among consumers, the retail businesses got a crucial opportunity to expand their market in organic food. The antecedents of TPB has positive influence on consumers' buying intentions towards organic food. This finding is coherent with Ajzen (1991) theory. Although, the TPB theory is considered as they relevant model that predict the different behavioral intentions, but the researchers claimed that the results are not always consistent because it depends on the situations and behaviors (Jasper and Waldhart, 2013). For instance, the results of Shim et al. (2001), Çabuk et al. (2014) and Njite and Parsa (2005) found attitude as stronger predictor of behavior but in specific situation. Additionally, Lee et al. (2015) and Tarkiainen and Sundqvist (2005) proposed that the purchasing attitude influences the consumer's behavioral intentions. But, some studialso find unclear relationship between attitude and purchase intentions (Lin and Chen, 2009).

The next dimension of TPB is subjective norms on which researchers argued that it is the weakest influence on buying intentions (Sparks et al., 1995). In contrast, the current study demonstrates subjective norm as well as attitude as strong predictor of purchase intentions towards organic food. Armitage and Conner
(2001) claimed that the researchers mostly used single-item construct to measure subjective norms that decreases the predictive power of the construct and also considered as inadequate measurement. The meta-analytical study of Armitage and Conner (2001) concluded that multiple-items construct of subjective norm has strong relationship purchase intentions when compared to single-item construct.

In spite of the significance of this study for an organic food market in both countries, this study also has some important limitations which should be undertaken in future research studies. Firstly, the sampling size and convenience sampling have foiled the generalizability of the results to the population. Hence, the future studies should increase the sample size and collect the data through probability sampling technique to get generalizability. Secondly, only food safety concern, environmental concern and health consciousness are taken as motivating factors to predict attitudes and purchase intentions. In order to expand more in-depth understanding of consumer behavior towards organic food consumptions, future studies should take quality, ethics, fashion, nostalgia, local economy status, animal health and taste into consideration. Finally, the future studies should incorporate mediating variables in said relationships.

\section{REFERENCES}

Ajzen, I. 1991. The Theory of Planned Behavior. Organizational Behavior and Human Decision Processes, 50 (2), 179-211.

Armitage, C. J. and Conner, M. 2001. Efficacy of the Theory of Planned Behaviour: A Meta-Analytic Review. British Journal of Social Psychology, 40 (4), 471-499.

Bredahl, L. 2001. Determinants of Consumer Attitudes and Purchase Intentions with Regard to Genetically Modified Food - Results of a Cross-National Survey. Journal of Consumer Policy, 24 (1), 23-61.

Çabuk, S., Tanrikulu, C. and Gelibolu, L. 2014. Understanding Organic Food Consumption: Attitude as a Mediator. International Journal of Consumer Studies, 38 (4), 337-345.
Chen, C.-D., Fan, Y.-W. and Farn, C.-K. 2007. Predicting Electronic Toll Collection Service Adoption: An Integration of the Technology Acceptance Model and the Theory of Planned Behavior. Transportation Research Part C: Emerging Technologies, 15 (5), 300-311.

Cheung, G. W. and Rensvold, R. B. 2002. Evaluating Goodness-of-Fit Indexes for Testing Measurement Invariance. Structural Equation Modeling: A Multidisciplinary Journal, 9 (2), 233-255.

Christoph, I. B., Bruhn, M. and Roosen, J. 2008. Knowledge, Attitudes Towards and Acceptability of Genetic Modification in Germany. Appetite, 51 (1), 58-68. 
DiPietro, R. B., Cao, Y. and Partlow, C. 2013. Green Practices in Upscale Foodservice Operations: Customer Perceptions and Purchase Intentions. International Journal of Contemporary Hospitality Management, 25 (5), 779-796.

Engelen, A. and Brettel, M. 2011. Assessing Cross-Cultural Marketing Theory and Research: Reply to Craig and Douglas' Commentary. Journal of Business Research, 64 (7), 782-784.

Godin, G. and KoK, G. 1996. The Theory of Planned Behavior: A Review of its Applications to Health-Related Behaviors. American Journal of Health Promotion, 11 (2), 87-98.

Gracia Royo, A. and de Magistris, T. 2007. Organic Food Product Purchase Behaviour: A Pilot Study for Urban Consumers in the South of Italy. Spanish Journal of Agricultural Research, 5 (4), 439-451.

Grønhøu, A. and Ölander, F. 2007. A Gender Perspective on Environmentally Related Family Consumption. Journal of Consumer Behaviour, 6 (4), 218-235.

Hamzaoui-Essoussi, L. and Zahaf, M. 2008. Decision Making Process of Community Organic Food Consumers: An Exploratory Study. Journal of Consumer Marketing, 25 (2), 95-104.

Hoefrens, C., Verbeke, W., Aertsens, J., Mondelaers, K. and VAn CAmp, J. 2009. The Nutritional and Toxicological Value of Organic Vegetables: Consumer Perception Versus Scientific Evidence. British Food Journal, 111 (10), 1062-1077.

Hofstede, G. 1991. Cultures and Organizations: Software of the Mind. London, UK: McGraw-Hill.

Honkanen, P., Verplanken, B. and Olsen, S. O. 2006. Ethical Values and Motives Driving Organic Food Choice. Journal of Consumer Behaviour, 5, 420-430.

Hsu, C. H. C and Huang, S. 2012. An Extension of the Theory of Planned Behavior Model for Tourists. Journal of Hospitality and Tourism Research, 36 (3), 390-417.

Hughner, R. S., McDonagh, P., Prothero, A., Shultz, C. J. and Stanton, J. 2007. Who Are Organic Food Consumers? A Compilation and Review of Why People Purchase Organic Food. Journal of Consumer Behaviour, 6 (2-3), 94-110.

Hwang, J. 2016. Organic Food as Self-Presentation: The Role of Psychological Motivation in Older Consumers' Purchase Intention of Organic Food. Journal of Retailing and Consumer Services, 28, 281-287.

IshaQ, M. I. and Di MARIA, E. 2018. Sustainability Countenance in Brand Equity: A Critical Review and Future Research Directions. Journal of Brand Management, in press.
JAsper, C. R. and Waldhart, P. 2013. Employer Attitudes on Hiring Employees with Disabilities in the Leisure and Hospitality Industry: Practical and Theoretical Implications. International Journal of Contemporary Hospitality Management, 25 (4), 577-594.

Kim, M.-J., LeE, C.-K., KIM, W. G. and KIM, J.-M. 2013. Relationships Between Lifestyle of Health and Sustainability and Healthy Food Choices for Seniors. International Journal of Contemporary Hospitality Management, 25 (4), 558-576.

KLine, R. B. 2011. Principles and Practice of Structural Equation Modeling. New York: Guilford Press.

LeA, E. and Worsley, T. 2005. Australians' Organic Food Beliefs, Demographics and Values, British Food Journal, 107 (11), 855-869.

Lee, K., Conklin, M., Cranage, D. A. and Lee, S. 2014. The Role of Perceived Corporate Social Responsibility on Providing Healthful Foods and Nutrition Information with Health-Consciousness as a Moderator. International Journal of Hospitality Management, 37, 29-37.

Lee, K.-H., Bonn, M. A. and Cho, M. 2015. Consumer Motives for Purchasing Organic Coffee: The Moderating Effects of Ethical Concern and Price Sensitivity. International Journal of Contemporary Hospitality Management, 27 (6), 1157-1180.

Lin, L.-Y. and Chen, Y.-W. 2009. A Study on the Influence of Purchase Intentions on Repurchase Decisions: the Moderating Effects of Reference Groups and Perceived Risks. Tourism Review, 64 (3), 28-48.

Lockie, S., Lyons, K., Lawrence, G. and Grice, J. 2004. Choosing Organics: A Path Analysis of Factors Underlying the Selection of Organic Food Among Australian Consumers. Appetite, 43 (2), 135-146.

Lodorfos, G. N. and Dennis, J. 2008. Consumers' Intent: in the Organic Food Market. Journal of Food Products Marketing, 14 (2), 17-38.

Magkos, F., Arvaniti, F. and Zampelas, A. 2006. Organic Food: Buying More Safety or Just Peace of Mind? A Critical Review of the Literature. Critical Reviews in Food Sciences and Nutrition, 46, 23-56.

Magnusson, M. K., Arvola, A., Koivisto Hursti, U.-K., Åberg, L. and Sjödén, P.-O. 2003. Choice of Organic Foods is Related to Perceived Consequences for Human Health and to Environmentally Friendly Behaviour. Appetite, 40 (2), 109-117. 
Manaktola, K. and Jauhari, V. 2007. Exploring Consumer Attitude and Behavior Towards Green Practices in the Lodging Industry in India. International Journal of Contemporary Hospitality Management, 19 (5), 364-377.

McCluskey, J. J., Grimsrud, K. M., Ouchi, H. and WahL, T. I. 2005. Bovine Spongiform Encephalopathy in Japan: Consumers' Food Safety Perceptions and Willingness to Pay for Tested Beef. Australian Journal of Agricultural and Resource Economics 49 (2), 197-209.

McEachern, M. G. and McClean, P. 2002. Organic Purchasing Motivations and Attitudes: Are They Ethical? International Journal of Consumer Studies, 26 (2), 85-92.

Michaelidou, N. and Hassan, L. M. 2008. The Role of Health Consciousness, Food Safety Concern and Ethical Identity on Attitudes and Intentions Towards Organic Food. International Journal of Consumer Studies, 32 (2), 163-170.

Nardali, S. and Ay, C. 2008. Değer Tabanlı Bölümlendirme Kapsamında Organik Ürün Tüketicilerini Motive Eden Kişisel Değerlerin Belirlenmesi. Marmara Üniversitesi Öneri Dergisi, 8 (29), 13-21.

Newsom, J. T., McFarland, B. H., Kaplan, M. S., Huguet, N. and Zani, B. 2005. The Health Consciousness Myth: Implications of the Near Independence of Major Health Behaviors in the North American Population. Social Science and Medicine, 60 (2), 433-437.

Nutte, D. and PArsa, H. G. 2005. Structural Equation Modeling of Factors that Influence Consumer Internet Purchase Intentions of Services. Journal of Services Research, 5, 43-59.

Pliner, P. and Hobden, K. 1992. Development of a Scale to Measure the Trait of Food Neophobia in Humans. Appetite, 19 (2), 105-120.

Rimal, A. P., Moon, W. and Balasubramanian, S. K. 2005. Agrobiotechnology and Organic Food Purchase in the United Kingdom. British Food Journal, 107 (2), 84-97.

Rimal, A. P., Moon, W. and Balasubramanian, S. K. 2006. Perceived Risks of Agro-Biotechnology and Organic Food Purchases in the United States. Journal of Food Distribution Research, 37 (2), 70-79.

Roberts, J. A. and BACon, D. R. 1997. Exploring the Subtle Relationships Between Environmental Concern and Ecological Conscious Consumer Behaviour. Journal of Business Research, 40 (1), 79-89.

Schifferstein, H. N. J. and Oude Ophuis, P. A. M. 1998. Health Related Determinants of Organic Food Consumption in the Netherlands. Food Quality and Preference, 9 (3), 119-133.
Shim, K., Blake, K. J., Jack, J., Krasnow, M. A 2001. The Drosophila Ribbon Gene Encodes a Nuclear BTB Domain Protein that Promotes Epithelial Migration and Morphogenesis. Development, 128 (23), 4923-4933.

Smith, S. and Paladino, A. 2010 Eating Clean and Green? Investigating Consumer Motivations Towards the Purchase of Organic Food. Australasian Marketing Journal, 18 (2), 93-104.

Sparks, P., Shepherd, R., Wieringa, N. and Zimmermanns, N. 1995. Perceived Behavioural Control, Unrealistic Optimism and Dietary Change: An Exploratory Study. Appetite, 24 (3), 243-255.

Squires, L., Juric, B. and Bettina Cornwell, T. 2001. Level of Market Development and Intensity of Organic Food Consumption: Cross-Cultural Study of Danish and New Zealand Consumers. Journal of Consumer Marketing, 18 (5), 392-409.

TARkiainen, A. and Sundqvist, S. 2005. Subjective Norms, Attitudes and Intentions of Finnish Consumers in Buying Organic Food. British Food Journal, 107 (11), 808-822.

Tsakiridou, E., Boutsouki, C., Zotos, Y. and Mattas, K. 2008. Attitudes and Behavior Towards Organic Products: An Exploratory Study. International Journal of Retail \& Distribution Management, 36 (2), 158-175.

Vandenberg, R. J. and Lance, C. E. 2000 A Review and Synthesis of the Measurement Invariance Literature: Suggestions, Practices, and Recommendations for Organizational Research. Organizational Research Methods, 3 (1), 4-70.

Verhoef, P. C. 2005. Explaining Purchases of Organic Meat by Dutch Consumers. European Review of Agricultural Economics, 32 (2), 245-267.

Williams, P. R. and Hammitt, J. K. 2000. A Comparison of Organic and Conventional Fresh Produce Buyers in the Boston Area. Risk Analysis, 20 (5), 735-746.

YADAV, R. 2016. Altruistic or Egoistic: Which Value Promotes Organic Food Consumption Among Young Consumers? A Study in the Context of a Developing Nation. Journal of Retailing and Consumer Services, 33, 92-97.

Yoo, M., Lee, S. and BAI, B. 2011. Hospitality Marketing Research from 2000 to 2009: Topics, Methods, and Trends. International Journal of Contemporary Hospitality Management, 23 (4), 517-532.

Zanoli, R. and Naspetti, S. 2002. Consumer Motivations in the Purchase of Organic Food: a Means-End Approach. British Food Journal, 104 (8), 643-653. 


\section{ANNEX}

Tab. 7: Study Questionnaire

\begin{tabular}{|c|c|c|}
\hline Scale & Measuring Items & Author(s) \\
\hline Attitude & $\begin{array}{l}\text { Purchasing organic food is useful } \\
\text { Organic food offers better quality than conventional food } \\
\text { I am strongly in favor of buying organic food }\end{array}$ & $\begin{array}{l}\text { Bredahl } \\
(2001)\end{array}$ \\
\hline $\begin{array}{l}\text { Subjective } \\
\text { Norm }\end{array}$ & $\begin{array}{l}\text { Those who are influential on what I do and think recommend my buying organic food } \\
\text { The majority of people who are important to me will help me purchase organic food } \\
\text { Most people who are important to me think positively of my buying organic food }\end{array}$ & $\begin{array}{l}\text { Bredahl } \\
(2001)\end{array}$ \\
\hline PBC & $\begin{array}{l}\text { I can afford time and money to purchase organic food } \\
\text { Purchasing organic food depend mostly upon to me } \\
\text { If I wanted to organic food, I could access it any time } \\
\text { Purchasing organic food is easy }\end{array}$ & $\begin{array}{l}\text { Bredahl } \\
(2001)\end{array}$ \\
\hline $\begin{array}{l}\text { Purchase } \\
\text { Intentions }\end{array}$ & $\begin{array}{l}\text { I definitely intend to buy organic food } \\
\text { I recommend that others buy organic food } \\
\text { I will try to purchase organic food in coming months } \\
\text { I would purchase organic food if I could find it easily }\end{array}$ & $\begin{array}{l}\text { Pliner and } \\
\text { Hobden (1992), } \\
\text { Bredahl (2001) }\end{array}$ \\
\hline $\begin{array}{l}\text { Food Safety } \\
\text { Concern }\end{array}$ & $\begin{array}{l}\text { Conventional food products are less safe to eat } \\
\text { Consumers want more organic produce } \\
\text { Organic foods are worth paying extra for } \\
\text { Consumers are willing to pay more for organic produce } \\
\text { Organic products taste better than non-organic products } \\
\text { Organic food offers more benefits to consumers } \\
\text { The quality and safety of non-organic food nowadays concerns me }\end{array}$ & $\begin{array}{l}\text { Hammitt (2000), } \\
\text { McEachern and } \\
\text { McClean (2002), } \\
\text { Michaelidou and } \\
\text { Hassan (2008) }\end{array}$ \\
\hline $\begin{array}{l}\text { Environmental } \\
\text { Concern }\end{array}$ & $\begin{array}{l}\text { The balance of nature is very delicate and can be easily upset. } \\
\text { Human beings are severely abusing the environment. } \\
\text { Humans must maintain the balance with nature in order to survive. } \\
\text { Human interferences with nature often produce disastrous consequences. }\end{array}$ & $\begin{array}{l}\text { Roberts } \\
\text { and Bacon } \\
(1997)\end{array}$ \\
\hline $\begin{array}{l}\text { Health } \\
\text { Consciousness }\end{array}$ & $\begin{array}{l}\text { I reflect about my health a lot } \\
\text { I'm very self-conscious about my health } \\
\text { I'm alert to changes in my health } \\
\text { I'm usually aware of my health } \\
\text { I take responsibility for the state of my health } \\
\text { I'm aware of the state of my health as I go through the day }\end{array}$ & $\begin{array}{l}\text { Michaelidou } \\
\text { and Hassan } \\
(2008), \\
\text { Squires } \\
\text { et al. (2001) }\end{array}$ \\
\hline
\end{tabular}

\section{AUTHOR'S ADDRESS}

Muhammad Ishtiaq Ishaq, Imperial College of Business Studies, Pakistan, e-mail ishaq.muhammadishtiaq@gmail.com 